\title{
Türkiye'de Toplumsal Cinsiyet Eşitsizliği-Ekonomik Büyüme İlişkisi Üzerine Ekonometrik Analiz
}

\author{
Zeynep ÇOLAK ${ }^{1}$
}

Öz

Kadının güçlendirilmesi ve konumunun geliştirilmesi ile toplumsal cinsiyet eşitliğinin sağlanmasının, ekonomik büyüme başta olmak üzere birçok makroekonomik değişken üzerinde etkisi olmaktadır. Bu çalışmada, Türkiye için 2005-2019 tarihleri arasında toplumsal cinsiyet eşitsizliğinin ekonomik büyümeye olan etkileri incelenmiştir. Çalş̧ma kapsamında TUIK ten elde edilen veriler ile oluşturulan denklemler LS-Least Squares (NLS ve ARMA) metoduyla analiz edilmiştir. Yapılan analizler sonucu, ekonomik büyümenin en çok ücretli çalş̧anlarda daha sonra ise lise ve dengi okul mezunu çalışanlarda cinsiyetler arası gelir eşitsizliği oranı üzerinde etkisinin olduğu görülmüştür. Ekonomik büyümenin, hem ücretli hem de lise ve dengi okul mezunu çalışanlardaki cinsiyetler arası gelir eşitsizliği oranını kadınların lehine olacak şekilde azaltan bir faktör olduğu tespit edilmiştir.

Anabtar Kelimeler: Cinsiyet Eşitsizliği, Ekonomik Büyüme, Beşeri sermaye, İnsani Gelişim, Gelir Eşitsizliği.

\section{Econometric Analysis on Gender Inequality and Economic Growth Relationship in}

\section{Turkey}

\section{Abstract}

Empowering and improving women's position and ensuring gender equality have an impact on many macroeconomic variables, particularly on economic growth. This study examines the effects of gender inequality on Turkey's economic growth between 2005-2019. The equations, which are created with the data from TUIK, were analyzed applying LS-Least Squares (NLS and ARMA) method. The result of the studies shows that economic growth had the greatest impact on gender wage gap mostly among employees and then graduates of high or equivalent schools. It has been revealed that economic growth is a factor that decreases the gender wage gap in favor of women, both among employees and high school graduates.

Key Words: Gender Inequality, Economic Growth, Human Capital, Human Development, Income Inequality.

\section{Atıf İçin / Please Cite As:}

Çolak, Z. (2021). Türkiye'de toplumsal cinsiyet eşitsizliği-ekonomik büyüme ilişkisi üzerine ekonometrik analiz. Manas Sosyal Arasstrmalar Dergisi, 10(2), 1094-1105.

Geliş Tarihi / Received Date: 23.03 .2020

Kabul Tarihi / Accepted Date: 14.01.2021

\footnotetext{
${ }^{1}$ Dr. Öğr. Üyesi - Çanakkale Onsekiz Mart Üniversitesi Biga İktisadi ve İdari Bilimler Fakültesi, zolak.84@gmail.com

(i) ORCID: 0000-0003-0058-6809
} 


\section{Giriş}

Ekonomik büyüme, ekonominin, üretim kapasitesinin ve verimliliğinin artması ile birlikte önceki dönemlere oranla, daha fazla hizmet ve mal üretmesidir. Bazı ülke ekonomileri, uzun süreler boyunca üretimde büyük artışlar elde eder ve bu artışlar ekonomik, politik ve sosyal alanı önemli ölçüde değiştirir.

Ekonomik büyüme bireylere, bölgelere ve uluslara daha fazla refah sağladığ1 sürece arzu edilen bir değişikliktir. Ekonomik büyümenin bazı faydaları ve maliyetleri vardır. Ekonomik büyümenin pozitif taraftı; yaşam standardını iyileştirmesi, yoksulluğu azaltmaya yardımcı olması, çalışma koşullarını iyileştirmesi ve işsizliği azaltmasıdır. Gelir ve tüketim arttırdığından dolayı da toplumlar için önemlidir, diğer bir deyişle, insanlar daha yüksek bir yaşam standardına sahip olur ve sosyal olarak arzu edilen mal ve hizmetleri üretme ve tüketme yeteneğini arttırır. Bu nedenle ekonomik büyüme insanları maddi olarak daha iyi hale getirir yani yüksek gelir seviyesi ve yüksek büyüme oranı daha az yoksulluk demektir.

Ekonomik büyümede önemli olan etken üretim ve dağıtımı arasındaki bağlantıdır. Çoğu araştırmacı, ekonomik büyümenin temel amacının toplumsal refahta iyileşme sağlamak olduğu konusunda hemfikirdir. Ancak kişi başına düşen gelirdeki artış, sosyal refahta iyileşmelerin gerçekleştiğini değil sadece sosyal refahı artırma potansiyelinin olduğunu gösterir, Sanayileşme-kalkınma stratejileri ve ekonomik büyüme politikaları, sosyal refahı arttırmak için sadece araçsal değişkenlerdir.

İnsanlara ekonomik olarak ne kadar eşit fırsatlar dağttılırsa, insan refahının yükselmesi için firsatlar doğmuş olur. Ekonomik büyüme yoksulluğun azaltılmasına katkıda bulunur, ancak büyümenin yoksul sayısında azalmaya dönüşme oranı gelir dağılımı seviyeleri de dahil olmak üzere birçok faktöre bağlıdır. Büyümenin gerçekleştiği ülkeler yoksulluğu azaltma eğilimindeyken, büyümenin daha düşük oranda olduğu ülkelerde tam tersi bir durum söz konusudur.

Bu nedenle, yaşam standartlarındaki artış ancak ekonomik büyümeden elde edilen kazanımlar ile tüm toplum tarafindan (zengin ve fakir kadınlar ve erkekler. eğitimli ve daha az eğitimli, kentsel ve kırsal, her kökenden insanlar) geniş bir şekilde paylaşılıyor ise elde edilebilir ve sürdürülebilir olur.

Özellikle toplumsal cinsiyet eşitliği ve refahın erkekler ve kadınlar arasında eşit olarak dağılımı, adil bir dağılım için çok önemli bir göstergedir. Dünyanın birçok yerinde kadınlar eğitim, çocuk bakımı, kredi ve istihdama daha iyi erişim için daha adil firsatlara sahiptir ve bu durum insani gelişimlerine katkıda bulunmaktadır. Ayrıca diğer aile üyelerinin insani gelişimlerine ve ekonomik büyümeye de katkıda bulunurlar. Kadınların yeteneklerine yatırım yapmak ve seçimlerini kullanmalarını sağlamak, ekonomik büyümeye ve genel gelişime katkıda bulunmanın en kesin yoludur.

1970'lerin başından itibaren ekonomik büyüme, yaşam koşullarında ve kadınların statüsünde insani gelişme ve iyileşme elde etmek için en etkili strateji olarak vurgulanmıştır. 1970 yılında yaptığı çalışmada Danimarkalı araştırmacı Ester Boserup (1970) kadın ve erkekler arasındaki eşitsizlikleri değerlendirmiş ve Afrika, Asya ve Latin Amerika'da yaptığı çalışmalarda, toplumsal cinsiyet eşitsizliklerinin ekonomik büyüme ile ilişkilendirmeden önce ülkelerin kalkınmasının belirli bir eşiğe ulaşması gerektiğini savunmuştur. Boserup kitabında, kalkınmanın ilk aşamalarında, ekonomik büyümeye ile birlikte artan kentleşme ve sanayileşme oranlarının evde ve işyerinde emeğin cinsel vizyonunu yoğunlaştırma eğiliminde olduğunu öne sürmüştür. İş alanlarının daha da genişlemesi, geleneksel toplumsal cinsiyet anlayışını değiştirmeye başlamış ve işgücü piyasaları, işverenlere kadınların ücretlerinin iyileştirilmesi ve kadınların ev dışında da çalışması için baskı yapmıştır (Boserup 1970 Akt: Toksöz, 2011: 48). Kuznets (1955) çalışmasında, iktisadi büyümenin erken aşamalarında güç ilişkilerinin, daha büyük eşitsizliğe yol açacak şekilde değişmekte olduğunu, ancak ileriki aşamalarda toplumsal eşitsizliği azaltacak bir eğilimin olduğunu savunmuşlardır (Kuznets, 1955: s.25).

Toplumsal cinsiyet ve ekonomik büyüme yaklaşımı, sosyalist feministlerden de etkilenmiştir. Sosyalist feministler; kadın dayanışmasının yanında erkeklerin de bu dayanışmaya katkı sunmasının önemli olduğuna vurgulamaktadır. Devlet desteği ile kadınların güçleneceğini hatta bu desteğin yerel kurumlar tarafindan da yapılması gerektiğini ve durumun bu biçimde daha sürdürülebilir olacağını savunmuşlardır. Diğer yandan kadınların politik alanda yer alabilmesi ya da mevcut yerlerini güçlendirmesi için örgütlenmeleri gerektiğini belirtilmektedirler. Kadınları güçlendiren toplumsal cinsiyet ve ekonomik büyüme yaklaşımı, toplum içerisinde kadın erkek arasında var olan güç ilişkilerinin bertaraf edilmesi gerektiğini savunmaktadırlar. Ekonomik büyüme ve kalkınmada kadın yaklaşımları; kadınları mevcut sisteme entegre etme amacında iken, toplumsal cinsiyet ve ekonomik büyüme yaklaşımları ise kadınların mevcut duruma entegre olma 
probleminden öte, toplum içerisinde var olan gücün adil bir şekilde dağılması gerektiğini savunmaktadırlar. Böylece kadınlar güçlenmekte ve kalkınma politikalarında sadece kaynakların erişebilir olması için faaliyetler gerçekleştirmek yerine politika düzenleme, yerel ve ulusal kurumların kadın ihtiyaçlarını odak noktası alarak yeniden düzenlenmesi için çalışmalar gerçekleştirmektedir (Baltacı, Karg1, Beken ve Akyol, 2017, s. 302; Miller ve Razavi, 1995, s.5).

Toplumsal cinsiyet eşitliği büyüme için önemli olup, kaynakların tam olarak kullanımını sağlar. Toplumsal cinsiyet eşitliği, kadın istihdamı ve ekonomik büyüme ilişkisini inceleyen çalışmaların en önemli sonuçlarından biri, kadınların işgücüne katılımı ve ekonomik büyüme arasında anlamlı bir ilişki olduğu ve toplumsal cinsiyet eşitsizliğinin olduğu ülkelerde de bu durumun büyümeye negatif olarak etki ettiği biçimindedir (Kilıç ve Öztürk, 2014, s. 108).

Cinsiyetçi yaklaşımlar çalışma hayatında kadının durumunu ve gelecekteki hedeflerini negatif yönde etkilemektedir. Toplumsal eşitsizlik bileşenleri arasındaki işgücüne katılım yüzdesinde kadının durumu Türkiye'de 2000 yllından itibaren gelişme kaydetmiş olsa dahi halen Türkiye dâhil birçok ülkede kadının çalışma hayatına girmesine yönelik birçok engel bulunmaktadır. Bu durum ise çalışma hayatında kadınların daha düşük ücret almasına neden olmaktadır (Koray, 2008, s. 45).

Bu çalışmanın amacı, Türkiye’nin 2007-2018 yılları arasında ekonomik büyümenin nasıl gerçekleştiğini ve bu dönemde kaydedilen ekonomik büyümenin; eğitim ve işteki durumlarına göre cinsiyetler arası gelir eşitsizliği üzerinde nasıl bir etkisi olduğunu araştırmaktır.

\section{Literatür Taraması}

Ekonomik büyüme ve toplumsal gelir eşitsizliği konusu araştırmacılar için her zaman önemli bir konu olmuştur. Deininger ve Squire (1996) eşitsizliğe dair 88 ülkeyi kapsayan on ylllk bir dönem için yeni bir veri seti oluşturmuşlardır. Yaptıkları analiz sonucunda, 45 ülkede ekonomik büyüme ile orantılı olarak gelir eşitsizliği artar iken ve 43 ülkede ise azaldığını tespit etmişlerdir (Deininger ve Squire. 1996, s.585).

Ravallion (1997) ekonomik büyüme ile gelir eşitsizliği arasında somut ampirik analizler yapmışlar ancak elde edilen veriler sonucunda büyümenin eşitsizliği artırma veya azaltma eğiliminde olmadı̆̆ sonucuna varmıslardır (Ravallion,1997, s.54).

Bruno, Ravallion ve Squire (1996)'nin Hindistan için yaptıkları çalışmada büyüme ile gelir eşitsizliği arasında sistematik bir iliş̧ki bulamamışlardır. Yaptıkları çalışmada Hindistan'daki yoksulluğun azalmasının sebebi olarak, kırsal sektörlerden kentsel sektörlere geçişten ziyade, kırsal ve kentsel sektörlerdeki gelişmelerden kaynaklandığını göstermişlerdir (Bruno, Ravallion ve Squire, 1996, s.18)

Forbes (2000) çalışmasında, gelir eşitsizliği üzerine, sadece ölçüm hatasını azaltmakla kalmayıp aynı zamanda bir panel tekniği ile kestirime izin veren gelişmiş bir veri seti kullanmıştır. Analizleri sonucunda, kısa ve orta vadede, bir ülkenin gelir eşitsizliği seviyesindeki artışın, daha sonraki ekonomik büyüme ile anlamlı bir pozitif ilişkiye sahip olduğunu göstermektedir (Forbes, 2000, s.870).

Barro (2000)'nin geniş bir ülke panelinden elde ettiği veriler sonucunda, gelir eşitsizliği ile büyüme ve yatırım oranları arasında çok az bir ilişki olduğunu göstermiştir. Yüksek eşitsizlik yoksul ülkelerde büyümeyi geciktirirken, daha zengin ülkelerde ise büyümeyi teşvik etme eğilimindedir (Barro, 2000, s.5).

Topuz ve Dağdemir (2016) 94 ülke için 1995-2011 dönemine ait verileri kullanarak yaptıkları çalışmada gelir eşitsizliği ve ekonomik büyüme arasındaki ilişkiyi sınamışlardır. 94 ülke gelir seviyesine göre gruplandırılarak iki değişken arasında oluşan ilişki ayrı ayrı panellerde incelenmiştir. Analiz sonuçlarına göre Ekonomik büyüme, düşük ve düşük-orta gelirli, üst-orta gelirli ülkelerde gelir eşitsizliğini artırıcı yönde iken yüksek gelirli ülkelerde ise azaltıcı bir rol oynamaktadır (Topuz ve Dağdemir, 2016, s.128).

Arora (2012), 1998-2006 döneminde Hindistan'daki cinsiyet eşitsizliğini, ekonomik kalkınmayı ve küreselleşmeyi incelemek için yaptı̆̆ çalışma sonucunda, kişi başına düssen gelirin milli gelir seviyesinin altında olması durumunda, düşük gelirin yüksek cinsiyet eşitsizliği ile ilişkili olması Hindistan'ın ekonomik büyümesi ve gelişimi üzerinde olumsuz bir etkiye sahip olduğunu göstermektedir (Arora, 2012, s.158).

Partovi, Safyar ve Amir (2011) çalışmasında 1966-2006 döneminde cinsiyet eşitsizliğinin ekonomik büyüme üzerindeki etkisi en küçük kareler yöntemini kullanarak incelemişlerdir. Sonuçlar, eğitimin İran'daki ekonomik büyüme üzerinde olumlu yönde etkiye sahip olduğunu ve eğitim ve istihdamda cinsiyet 
eşitsizliğini azalttı̆̆ını, ekonomik büyümenin de arttığını göstermektedir. Kadınlar için ortalama eğitim süresinin artmastyla birlikte ekonomik büyüme de artmaktadır (Partovi, Safyar ve Amir, 2011,s.70)

Seguino (2000) yaptığı çalışmada cinsiyet eşitsizliği ile ekonomik büyüme arasındaki ilişkiyi araştırmıştır. Hipotezi ise işgücü piyasasındaki cinsiyet eşitsizliğinin ve kadınların daha düşük olan ücretlerinin, ihracat sektörünün gelişmesiyle GSYIHH büyümesine yol açıp açmadığıdır. Ampirik analizler, 1995-1975 döneminde GSYİH büyümesinin cinsiyet eşitsizliği ile pozitif ilişkili olduğunu göstermektedir (Seguino, 2000, s.1225)

Münih Üniversitesi'nden Klasen (1999), 1960-1992 ylları arasında ekonomik büyümenin, cinsiyet eşitsizliği faktörleri tarafından olası azaltılmasının geniş kapsamlı istatistiksel analizini yayınlamış ve ülkeler arası yaptığ panel regresyon analizleri sonucunda cinsiyet eşitsizliğinin kayda değer ve olumsuz bir etkisi olduğunu tespit etmiştir (Klasen, 1999, s.12).

Dollar ve Gatti (1999)'nin bulguları Klasen'in bulgularını destekler niteliktedir. Yaptıkları çalışmada kişi başına düşen yüksek GSMH ile düşük cinsiyet eşitsizliği arasında bir korelasyon bulmuşlardır (Dollar ve Gatti, 1999, s.58).

\section{Yöntem}

\section{Araştırma Deseni}

Bu çalışmada Türkiye'nin 2005-2019 yllları arasındaki ekonomik büyümenin cinsiyetler arası gelir eşitsizliğine olan etkisi incelenmiştir. İlişkisel tarama modelinde gerçekleştirilen bu araştırma kapsamında nicel araştırma yönteminden faydalanılmıştır. Tarama modeli kullanılan araştırmalarda mevcut durum aynen resmedilerek var olan olduğu gibi tespit edilmeye çalışıllır. İlişkisel tarama modeli, tarama modelinin bir çeşidi olup; iki ya da daha çok değişken arasındaki ilişkiyi incelemeyi esas alır (Karasar, 2018, s.53).

\section{Veri Toplama Araçları}

Bu çalışmada Türkiye'nin 2005-2019 yıllarında kaydedilen ekonomik büyümenin cinsiyetler arası gelir eşitsizliğine olan etkisinin ortaya konulması amaçlanmıştır. Araştırma kapsamında "2005-2019 döneminde Türkiye'de ekonomik büyümenin; eğitim ve işteki durumlarına göre cinsiyetler arası gelir eşitsizliği üzerinde nasıl bir etkisi olmuştur?” sorusuna cevap aranmıştır.

Bu kapsamda oluşturulan denklemler aşağıda yer almaktadır.

$$
\begin{aligned}
& \text { ucretli1 } 1_{\mathrm{t}}=\beta_{0}+\beta_{1} \text { eko_buyume } 2_{\mathrm{t}}+\varepsilon_{\mathrm{t}} \\
& \text { yevmiyeli1 } 1_{\mathrm{t}}=\beta_{0}+\beta_{1} \text { eko_buyume } 2_{\mathrm{t}}+\varepsilon_{\mathrm{t}} \\
& \text { isveren } 1_{\mathrm{t}}=\beta_{0}+\beta_{1} \text { eko_buyume } 2_{\mathrm{t}}+\varepsilon_{\mathrm{t}} \\
& \text { kendihesabina } 1_{\mathrm{t}}=\beta_{0}+\beta_{1} \text { eko_buyume } 2_{\mathrm{t}}+\varepsilon_{\mathrm{t}} \\
& \text { okuryazarolmyn } 1_{\mathrm{t}}=\beta_{0}+\beta_{1} \text { eko_buyume } 2_{\mathrm{t}}+\varepsilon_{\mathrm{t}} \\
& \text { birokulbitirmyn } 1_{\mathrm{t}}=\beta_{0}+\beta_{1} \text { eko_buyume } 2_{\mathrm{t}}+\varepsilon_{\mathrm{t}} \\
& \text { lisealti1 } 1_{\mathrm{t}}=\beta_{0}+\beta_{1} \text { eko_buyume } 2_{\mathrm{t}}+\varepsilon_{\mathrm{t}} \\
& \text { lisevedengi1 } 1_{\mathrm{t}}=\beta_{0}+\beta_{1} \text { eko_buyume } 2_{\mathrm{t}}+\varepsilon_{\mathrm{t}} \\
& \text { yuksekogr } 3_{\mathrm{t}}=\beta_{0}+\beta_{1} \text { eko_buyume } 2_{\mathrm{t}}+\varepsilon_{\mathrm{t}}
\end{aligned}
$$

Denklemlerde yer alan;

“ucretli” ifadesi, ücretli çalışanlarda erkek/kadın çalışan gelir eşitsizliği yüzdelik oranını;

"yevmiyeli” ifadesi, yevmiyeli çalışanlarda erkek/kadın çalışan gelir eşitsizliği yüzdelik oranını;

“isveren” ifadesi, işveren olarak çalışanlarda erkek/kadın çalışan gelir eşitsizliği yüzdelik oranını; oranini;

"kendihesabina" ifadesi, kendi hesabına çalısanlarda erkek/kadın çalışan gelir eşitsizliği yüzdelik

"okuryazarolmyn" ifadesi eğitim seviyesi olarak okur-yazar olmayan çalşsanlarda erkek/kadın çalışan gelir eşitsizliği yüzdelik oranını; 
"birokulbitirmyn" ifadesi eğitim seviyesi olarak bir okul bitirmeyen çalışanlarda erkek/kadın çalışan gelir eşitsizliği yüzdelik oranını;

"lisealti” ifadesi eğitim seviyesi olarak lise altı çalışanlarda erkek/kadın çalışan gelir eşitsizliği yüzdelik oranini;

"lisevedengi" ifadesi eğitim seviyesi olarak lise ve dengi çalışanlarda erkek/kadın çalışan gelir eşitsizliği yüzdelik oranını;

"yuksekogr" ifadesi eğitim seviyesi olarak yüksek öğrenim görmüş çalışanlarda erkek/kadın çalışan gelir eşitsizliği yüzdelik oranını;

“eko_buyume” ifadesi ekonomik büyümenin yüzdelik oranını;

"1" ifadesi birinci dereceden farkı alınmış;

“2” ifadesi ikinci dereceden farkı alınmış;

“3” ifadesi üçüncü dereceden farkı alınmış olduğunu ifade etmektedir. Erkek/kadın çalışan gelir eşitsizliği yüzdelik oranı “(Erkek ücreti-kadın ücreti)/erkek ücreti *100” formülüyle hesaplanmıştır. Bu nedenle gelir eşitsizliklerindeki yüzdelik oranlar pozitif olması durumunda erkeklerin kadınlardan o kadar oranda daha yüksek gelir elde ettiği; negatif olması durumunda ise tam tersine kadınların erkeklerden o kadar oranda daha yüksek gelir elde ettiği anlamına gelmektedir.

Araştırma kapsamında tüm veriler Türkiye İstatistik Kurumu (TÜIK) resmi web sitesinden (www.tuik.gov.tr) elde edilmiştir. Araştırma kapsamındaki değişkenlere ait grafikler aşağıda sunulmuştur.

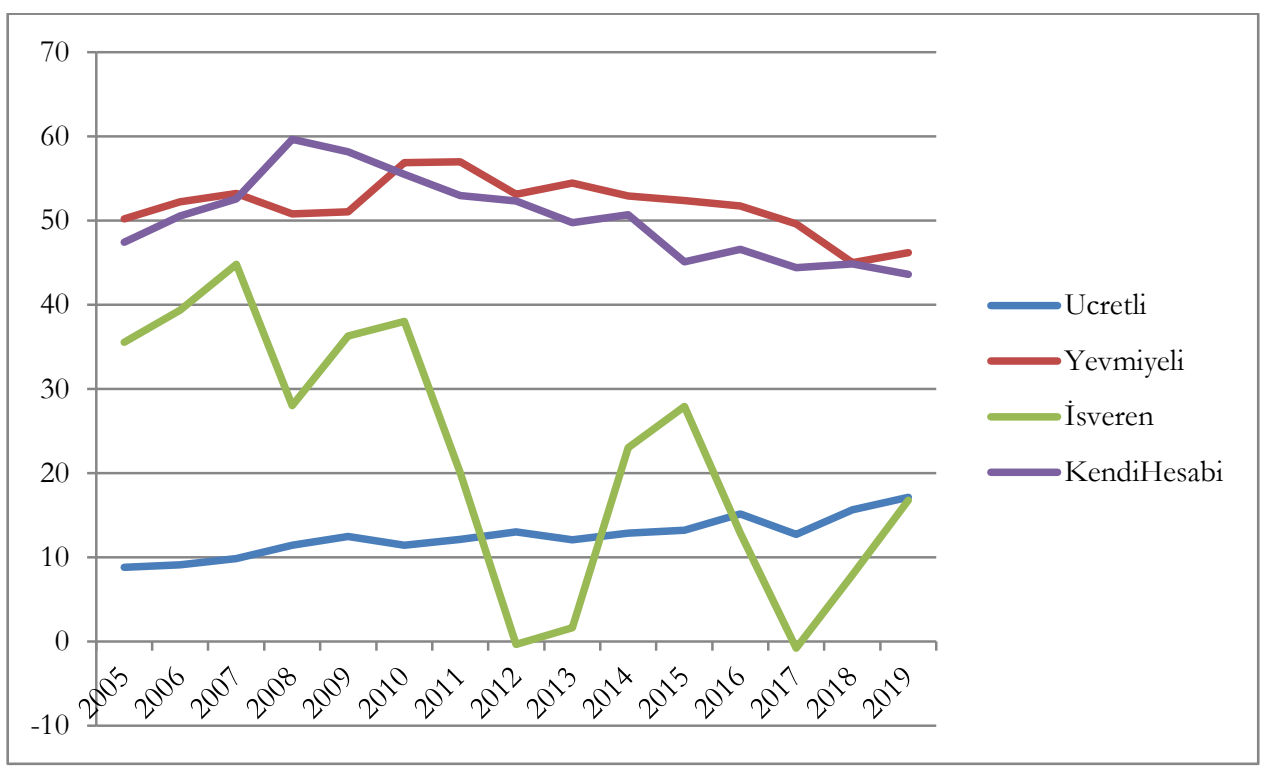

Grafik 1. 2005-2019 Issteki Durumlarna Göre Callsanlarda Cinsiyetler Arası Gelir Eşitsizligüi Oranlar

2005-2019 yılları arasındaki işteki durumlarına göre çalışanlarda cinsiyetler arası gelir eşitsizliği oranları Grafik 1'de sunulmuştur. Bu dönemdeki ücretli çalışanlarda cinsiyetler arası gelir eşitsizliği oranları incelendiğinde; çok küçük dalgalanmalar hariç stabil olduğu ve oranların \%9 ile \%17 arasında değiştiği görülmektedir. Yevmiyeli çalışanlarda cinsiyetler arası gelir eşitsizliği oranları incelendiğinde; 2005-2007 arası hafif bir yükseliş, 2007-2008 arası hafif bir düşüş, 2008-2009 arasında yatay bir seyir izlediği, 20092010 arasında doğrusal bir artış, 2010-2011 arasındaki yatay bir seyri müteakip sürekli hafif bir düşüş trendine girdiği ve oranların $\% 50$ ile $\% 57$ arasında değiştiği görülmektedir. Kendi hesabına çalışanlarda cinsiyetler arası gelir eşitsizliği oranları incelendiğinde ise; 2005-2008 arası doğrusal bir artış, 2008'den sonraki dönemde ise birkaç küçük istisna hariç hafif düşüş trendi gösterdiği ve oranların \%44 ile \%60 arasında değiştiği görülmektedir. İşteki durumlarına göre çalışanlarda cinsiyetler arası gelir eşitsizliği oranları en çok işveren konumundaki çalışanlarda dalgalanma göstermektedir. 2005-2007 arasında doğrusal bir yükseliş, 2007-2008 arasında sert bir düşüş, 2008-2009 arası doğrusal bir yükseliş, 2009-2010 arası çok hafif bir yükselişin ardından 2010-2012 aras1 çok sert bir düşüş, 2010-2013 arası çok hafif bir yükseliş, 2013-2014 arası sert yükselişin 2014-2015 arasında hafif bir yükselişe dönüştüğ̈̈̈, 2015-2017 arasında çok sert bir düşüşün ardından 2017-2019 arası doğrusal bir yükseliş olduğu görülmektedir. 


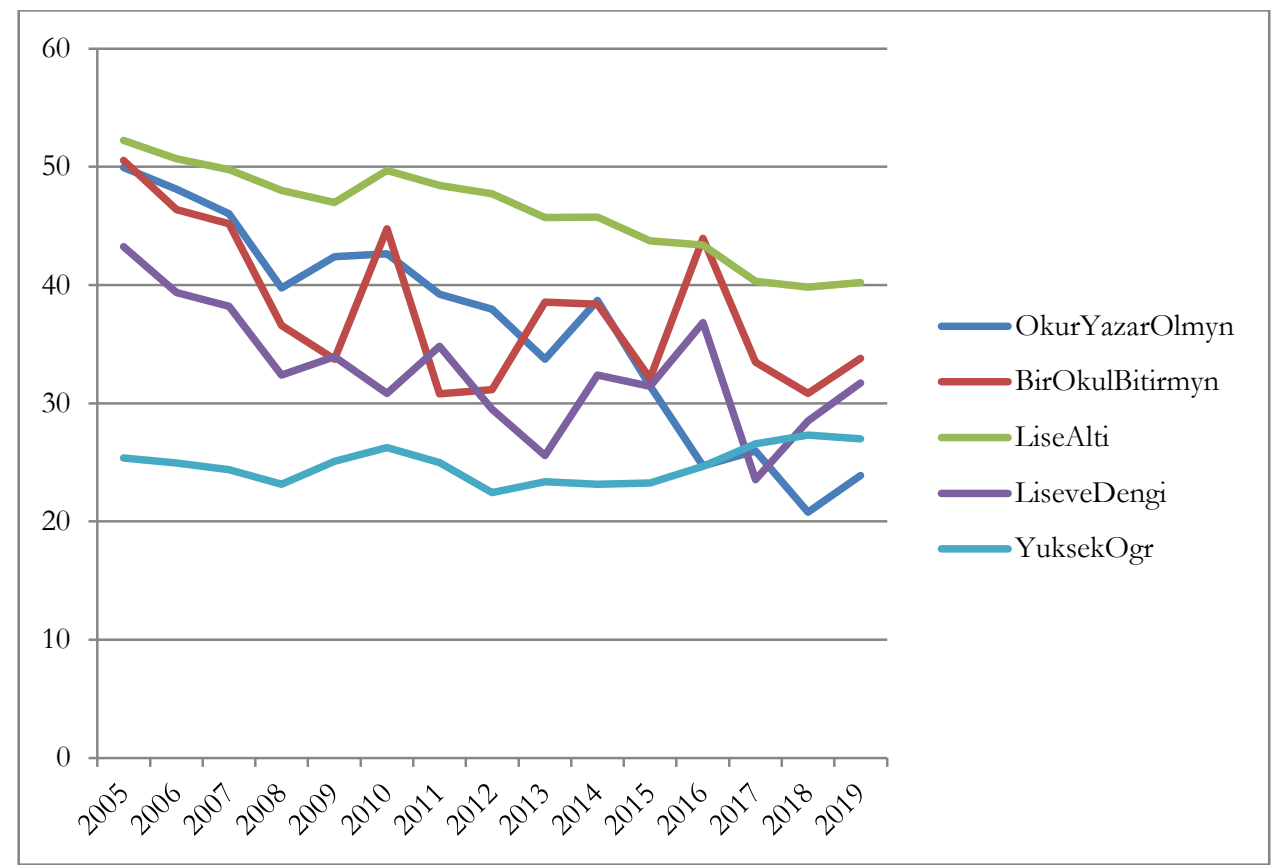

Grafik 2. 2005-2019 Ĕ̈itim Durumlarna Göre Calışanlarda Cinsiyetler Arası Gelir Eşsitsizliği Oranları Grafiği

2005-2019 yılları arasındaki eğitim durumlarına göre çalışanlarda cinsiyetler arası gelir eşitsizliği oranları Grafik 2'de sunulmuştur. Bu dönemdeki yüksek öğretim mezunu çalışanlarda cinsiyetler arası gelir eşitsizliği oranları incelendiğinde; çok küçük dalgalanmalar hariç stabil olduğu ve oranların \%22 ile \%27 arasında değiştiği görülmektedir. Lise ve altı okul mezunu çalışanlarda cinsiyetler arası gelir eşitsizliği oranları incelendiğinde; birkaç hafif yükselişin olduğu istisnai dönemler hariç hafif düşüş trendi olduğu ve oranların \%40 ile \%53 arasında değiştiği görülmektedir. Okur-yazar olmayan çalışanlarda da benzer şekilde birkaç hafif yükselişin olduğu istisnai dönemler hariç düşüş trendi olduğu ve oranların \%20 ile \%50 arasında değiştiği görülmektedir. Bir okul bitirmeyen çalışanlarda ise belirgin dalgalanmalar görülmektedir. Bu çalışanlardaki cinsiyetler arası gelir eşitsizliği oranları 2005-2006 arası doğrusal, 2006-2007 arası hafif, 2007-2008 arası sert, 2008-2009 arası ise doğrusal bir şekilde düşüş göstermiş, 2009-2010 arası set yükseliş, 2010-2011 arası ise tam tersine sert düşüş yaşamıs, 2011-2012 arası yatay bir seyri müteakip 2012-2013 aras1 doğrusal bir yükseliş, 2013-2014 arası yatay bir seyir, 2014-2015 arası sert bir düşüşün hemen ardından 2015-2016 arası sert bir yükseliş göstermiş, 2016'dan sonra tekrar düşüş trendine girerek 20162017 arası sert ve 2017-2018 arası doğrusal bir şekilde düşüş yaşamışsa da 2018-2019 arası doğrusal bir yükseliş yaşamış ve oranlar \%30 ile \%45 arasında değişiklik göstermiştir. Lise ve dengi mezunu çalışanlarda da belirgin dalgalanmalar görülmektedir. Bu çalışanlardaki cinsiyetler arası gelir eşitsizliği oranları 20052006 arası doğrusal, 2006-2007 arası hafif, 2007-2008 arası doğrusal şekilde düşse de 2008-2009 arası hafif bir yükseliş göstermiş, 2009-2010 arası doğrusal bir düşüşün ardından 2010-2011 arası doğrusal bir yükseliş yaşamış, 2011-2013 arası tekrar doğrusal bir şekilde düşüş göstermiş, 2013-2014 arası sert bir yükseliş, 2014-2015 arası ise çok hafif bir düşüş yaşamış, 2015-2016 arası doğrusal bir yükselişin ardından 20162017 arası sert bir düşüş, 2017-2019 aras1 ise doğrusal bir yükseliş göstermiştir ve oranlar \%23 ile \%44 arasında değişmiştir. 


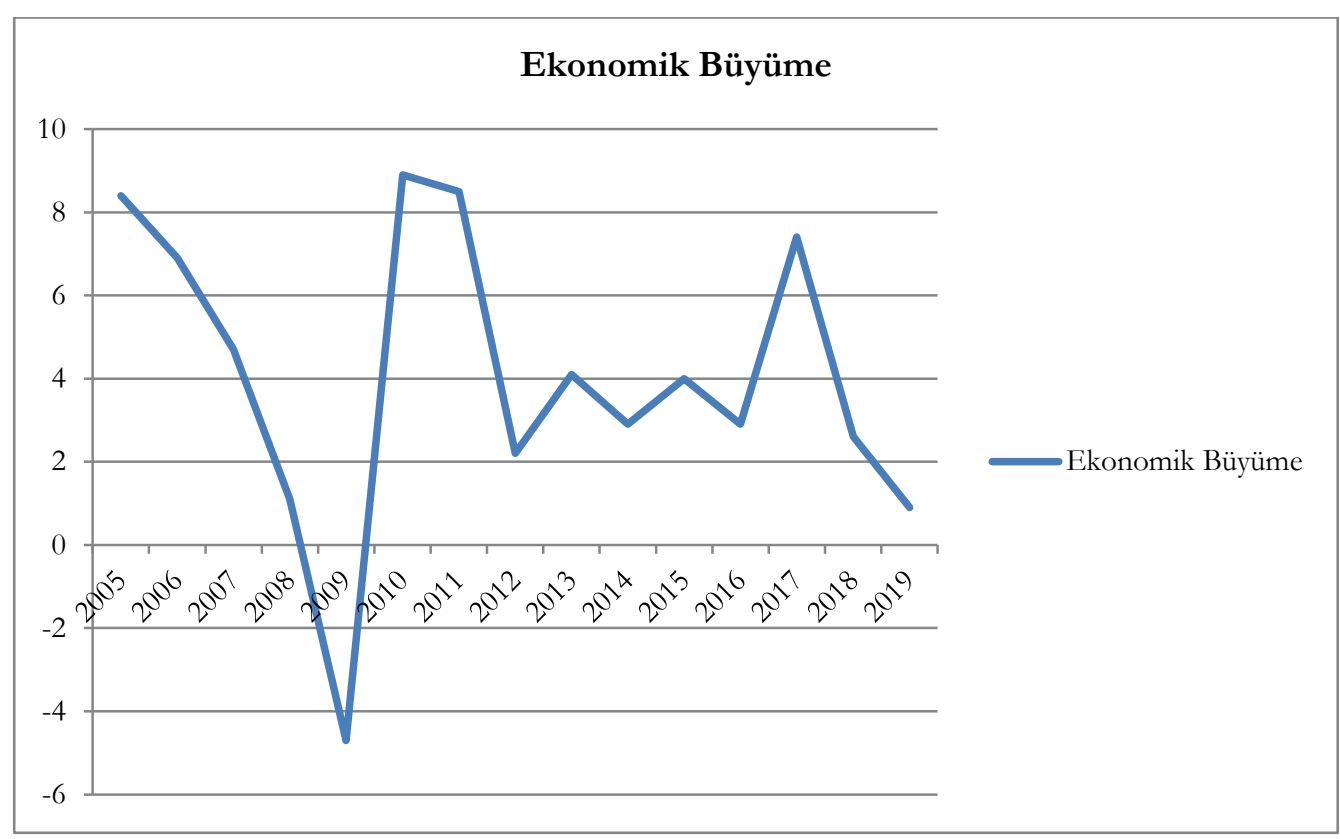

Grafik 3. 2005-2019 yullar arasindaki Türkiye'nin ekonomik büyüme oranlar

Türkiye'nin 2005-2019 yılları arasındaki ekonomik büyüme oranları Grafik 3'te sunulmuştur. 20052007 arasında Türkiye'nin ekonomik büyümesindeki doğrusal düşüş, 2007-2009 arası daha da sertleşmiş ve 2009 yllında -\%4,7 olarak negatif bir değer almış, yani Türkiye ekonomisi 2009 yllında \%4,7 küçülmüştür. 2009-2010 arası çok sert yükselen ekonomik büyüme, 2010'da en yüksek değerine (\%8,9) ulaşmıştır. 20102011 arası yatay bir seyir izleyen ekonomik büyüme, 2011-2012 arası sert bir düşüş göstermiş, 2012-2013 arası doğrusal yükseliş, 2013-2014 arası ise doğrusal bir düşüş yaşamıştır. 2014-2015 arası doğrusal bir yükseliş gösteren ekonomik büyüme oran1, 2015-2016 arası doğrusal bir şekilde düşüş, 2016-2017 arası sert bir yükseliş ve son olarak 2017-2019 arası yine sert bir düşüş göstermiştir.

\section{Verilerin Analizi}

Analiz sonuçlarının güvenilirliği açısından öncelikle serilerin durağan olması gerekmektedir. Durağan olmayan zaman serileri ile yapılan analizlerde sahte regresyon problemi ortaya çıkmaktadır. Bu nedenle öncelikle verilerin durağanlaştırılması amacıyla logaritma ve fark alma işlemleri yapılmış; verilerin durağanlıklarının kontrolü ise Augmented Dickey Fuller (ADF) testi ile test edilmiştir (Gujarati, 1999, s. 726 Akt: Kılıç ve Torun, 2018, s. 25). Bağımsız değişken olan "Ekonomik Büyüme”nin bağımlı değişkenler olan ücretli, yevmiyeli, işveren, kendi hesabına, okur-yazar olmayan, bir okul bitirmeyen, lise altı, lise ve dengi ile yüksek öğrenim görmüş çalışanlarda erkek/kadın çalışan gelir eşitsizliği üzerindeki etkisinin incelenmesinde ise LS-Least Squares (NLS ve ARMA) metodu kullanılmışır (Güriş, Akay ve Güriş, 2017, s. 123-126).

\section{Bulgular}

\section{Verilerin Analize Hazır Hale Getirilmesi}

Araştırma kapsamındaki tüm değişkenlere ait veri setleri bir trende sahip olduğundan öncelikle verilerin durağan hale getirilmesi için fark alma işlemi uygulanmıştır. Daha sonra verilerin durağanlıkları Augmented Dickey Fuller (ADF) birim kök testi ile kontrol edilmiştir. Tablo 1'de nihai ADF kök birim testi sonuçları yer almaktadır. 
Tablo 1.Nibai ADF kök birim testi sonuçlar

\begin{tabular}{|c|c|c|c|c|c|c|}
\hline \multirow{3}{*}{ Değişken } & \multicolumn{6}{|c|}{ Düzey Değerleri } \\
\hline & \multicolumn{2}{|c|}{ Sabit Terim ve Trend Yok } & \multicolumn{2}{|c|}{ Sabit Terim Var } & \multicolumn{2}{|c|}{ Sabit Terim ve Trend Var } \\
\hline & Test İst. & Olasılik & Test İst. & Olasılık & Test İst. & Olasılik \\
\hline ucretli1 & -5.298 & .000 & -4.239 & .009 & -4.167 & .047 \\
\hline yevmiyeli1 & -2.346 & .023 & -5.521 & .005 & -5.465 & .008 \\
\hline isveren1 & -4.937 & .000 & -5.916 & .001 & -10.989 & .000 \\
\hline kendihesabina1 & -4.933 & .000 & -6.797 & .000 & -5.663 & .006 \\
\hline okuryazarolmyn1 & -4.198 & .000 & -4.683 & .006 & -4.478 & .035 \\
\hline birokulbitirmyn1 & -8.933 & .000 & -7.849 & .000 & -5.721 & .007 \\
\hline lisealti1 & -3.628 & .004 & -3.991 & .016 & -4.773 & .020 \\
\hline lisevedengi1 & -7.805 & .000 & -5.967 & .001 & -5.331 & 010 \\
\hline yuksekogr3 & -3.864 & .002 & -3.575 & .040 & -4.481 & .044 \\
\hline eko_buyume2 & -8.937 & .000 & -6.793 & .000 & -5.207 & 018 \\
\hline
\end{tabular}

Sonuçlar incelendiğinde ücretli, yevmiyeli, işveren, kendi hesabına çalışanlar ile okur-yazar olmayan, bir okul bitirmeyen, lise ve altı ve lise ve dengi mezun çalışanlardaki cinsiyetler arası gelir eşitsizliği oranlarının birinci dereceden; ekonomik büyüme oranının ikinci dereceden; yükseköğretim mezunu çalışanlardaki cinsiyetler arası gelir eşitsizliği oranının üçüncü dereceden durağan oldukları görülmektedir.

\section{Ekonomik Büyümenin Cinsiyetler Arası Gelir Eşitsizliğine Olan Etkisinin Analizleri}

Ekonomik büyümenin cinsiyetler arası gelir eşitsizliğine olan etkileri LS-Least Squares (NLS ve ARMA) testi ile analiz edilmiştir. Araştırma kapsamında oluşturulan 9 adet denklem test edilerek sonuçları Tablo 2'de sunulmuştur.

Tablo 2. LS-Least Squares (NLS ve ARMA) Test Sonuclar

\begin{tabular}{|c|c|c|c|c|c|c|c|}
\hline Bağımlı Değişken & Katsayi & Std. Hata & $R^{2}$ & Düz. $R^{2}$ & $\bar{t}$ & $F$ & $P$ \\
\hline ucretli1 & -.103 & .039 & .473 & .411 & -2.125 & 7.4332 & $.029 * *$ \\
\hline yevmiyeli1 & .082 & .085 & .171 & .075 & 1.125 & 2.754 & .198 \\
\hline isveren1 & .255 & .493 & .032 & -.071 & .521 & .263 & .624 \\
\hline kendihesabina1 & -.073 & .061 & .131 & .029 & -1.049 & 1.237 & .297 \\
\hline okuryazarolmyn1 & .045 & .122 & .019 & -.073 & .428 & .187 & .685 \\
\hline birokulbitirmyn1 & .071 & .062 & .268 & .181 & 1.137 & 3.032 & .128 \\
\hline lisealti1 & .037 & .031 & .085 & -.002 & .963 & .911 & .387 \\
\hline lisevedengi1 & -.115 & .038 & .461 & .402 & -2.157 & 6.318 & $.032 * *$ \\
\hline yuksekogr3 & .005 & .006 & .016 & .005 & .289 & .089 & .772 \\
\hline
\end{tabular}

Bağımsız Değişken: eko_buyume2, ${ }^{*} \mathrm{p}<.01,{ }^{* *} \mathrm{p}<.05,{ }^{* * *} \mathrm{p}<.1$

Oluşturulan denklemlerde bağımsız değişken olarak ekonomik büyüme oranı; bağımlı değişkenler olarak ise işteki durumlarına göre cinsiyetler arası gelir eşitsizliği oranlanı (Ücretli, yevmiyeli, işveren, kendi hesbına çalışanlarda cinsiyetler arası gelir eşitsizliği oranları) ile eğitim durumuna göre çalışanlarda cinsiyetler arası gelir eşitsizliği oranları (Okur-yazar olmayan, bir okul bitirmeyen, lise ve alt1, lise ve dengi ve yükseköğretim mezunu çalışanlarda cinsiyetler arası gelir eşitsizliği oranları) kullanılmıştır.

Sonuçlar incelendiğinde ekonomik büyümenin $\% 95$ güven düzeyinde ücretli çalşsanlardaki cinsiyetler arası gelir eşitsizliği oranı $(\mathrm{p}=.029<.05)$ ile lise ve dengi okul mezunu çalışanlardaki cinsiyetler arası gelir eşitsizliği oranı $(\mathrm{p}=.032<.05)$ üzerinde etkisinin olduğu görülmektedir. Ekonomik büyüme katsayısının, hem ücretli hem de lise ve dengi okul mezunu çalısanlardaki cinsiyetler arası gelir eşitsizliği oranı ile olan denklemlerinde negatif bir değere sahip olduğu görülmektedir. Bu durum ekonomik büyüme oranındaki artışın ücretli çalışanlar ile lise ve dengi okul mezunu çalışanlardaki cinsiyetler arası gelir eşitsizliği oranını kadınların lehine olacak şekilde azalttığını göstermektedir.

Yevmiyeli, işveren, kendi hesabına çalışanlar ile okur-yazar olmayan, bir okul bitirmeyen, lise ve altı ve yükseköğretim mezunu çalışanlardaki cinsiyetler arası gelir eşitsizliği oranları üzerinde ise ekonomik büyüme oranının anlamlı bir etkisinin olmadığ tespit edilmiştir

\section{Tartışma, Sonuç ve Öneriler}

Seguino (2000) yaptığı çalışmada cinsiyet eşitsizliği ile ekonomik büyüme arasındaki ilişkiyi araştırmıştır.1995-1975 tarihleri arasında ülkeler arası yaptı̆ı ampirik analizler sonucunda, GSYİH büyümesinin, gelir eşitsizliğinin ekonomik büyümeyi yavaşlattığını gösteren son çalışmaların aksine, toplumsal cinsiyet ücret eşitsizliği ile olumlu ilisskili olduğunu göstermiştir. Ülkeler arası panel regresyonları 
kullanan Klasen (1999), eğitim ve istihdamdaki cinsiyet eşitsizliklerinin büyüme ve gelişmeyi ne ölçüde azaltabileceğini göstermiştir. Düşük işgücü kalitesi (beşeri sermaye) nedeniyle eğitimdeki cinsiyet eşitsizlikleri ekonomik büyüme üzerinde doğrudan etkiye sahipken, yatırım ve nüfus artışı dolaylı olarak ekonomik büyüme üzerinde etkili olmaktadır. Rashmi (2012)'da, 2006-1998 döneminde Hindistan için cinsiyet eşitsizliğini, ekonomik kalkınmayı ve küreselleşmeyi inceleyen bir çalışma sonucunda, kişi başına düşen gelirin milli gelir seviyesinin altında olması durumunda, düşük gelirin yüksek cinsiyet eşitsizliği ile ilişkili olması Hindistan'ın ekonomik büyümesi ve gelişimi üzerinde olumsuz bir etkiye sahip olduğunu göstermiştir.

Partovi, Safyar ve Amir (2011) çalışmasında 1966-2006 döneminde cinsiyet eşitsizliğinin ekonomik büyüme üzerindeki etkisi en küçük kareler yöntemini kullanarak incelemişlerdir. Sonuçlar, eğitimin İran'daki ekonomik büyüme üzerinde olumlu yönde etkiye sahip olduğunu ve eğitim ve istihdamda cinsiyet eşitsizliğini azalttığını, ekonomik büyümenin de arttığını göstermektedir. Kadınlar için ortalama eğitim süresinin artmasıyla birlikte ekonomik büyüme de artmaktadır.

Aytekin (2014) 'nin yaptığı çalışmalar sonucunda Türkiye'de farklı kategorilerde ortaya çıkan cinsiyet eşitsizliği sorununun, kadın emeğinin olumsuz etkilediği sonucu elde edilmiştir. Türkiye'de cinsiyet eşitsizliği sonuçlanı, özellikle kadın emeğinin ekonomik katılımcılı̆̆ında ortaya çıkmaktadır. Ayrıca eğitim olanaklarının belirlediği beşeri sermaye gücü yetersizliği ve düşük gelir sorunu cinsiyete bağlı olarak ortaya çıkan önemli gelir eşitsizliklerinden biri olmaktadır. Gürler ve Üçdoğruk (2007) yaptıkları analizler sonucunda meslek grupları dikkate alındığında, kanun yapıcı, üst düzey yönetici ve profesyonel mesleklerde çalışmanın kadın ve erkeklerin gelirleri üzerine etkisinin fazla olduğu görülmektedir. Ayrıca yaptıkları çalışmada Türkiye'de cinsiyetler arasında önemli boyutlarda ayrımcilığın olduğu saptanmıştır. Kasnakoğlu ve Dayığlu (1997) yaptıkları analiz sonucunda kamu sektöründe cinsiyete göre ücret farklılı̆̆ının yok denecek kadar az olduğunu göstermişlerdir. Tansel (2005) ise özel sektörde tarım dış1 çalışanlara dair kadın ve erkek ücret farklılığını araştırmışıı. Çalışmanın sonucuna göre kadınların ortalama ücretlerinin erkeklerin ortalama ücretlerine oranını 0,77 olarak bulmuştur. Ayrıca kadın erkek ücret farkllıklarının sektöre göre değişebileceğini belirtmiştir.

Yapılan çalısmanın uygulama kısmında 2005-2019 yıllarında kaydedilen ekonomik büyümenin işteki durumlarına göre cinsiyetler arası gelir eşitsizliği oranları (Ücretli, yevmiyeli, işveren, kendi hesabına çalışanlarda cinsiyetler arası gelir eşitsizliği oranları) ile eğitim durumuna göre çalışanlarda cinsiyetler arası gelir eşitsizliği oranlarına (Okur-yazar olmayan, bir okul bitirmeyen, lise ve altı, lise ve dengi ve yükseköğretim mezunu çalışanlarda cinsiyetler arası gelir eşitsizliği oranları) olan etkileri analiz edilmiştir.

2005-2019 yılları arasında ekonomik büyümenin küresel piyasalarda krizin yaşandığ1 2008 yllında neredeyse hiç gerçekleşmediği, 2009 yllında ekonomik büyümenin negatif bir değer alarak bu yılda ekonominin daraldığı, bu iki yll haricindeki yıllarda ise ekonomik büyümenin pozitif olarak gerçekleştiği görülmektedir.

Araştırma kapsamında oluşturulan denklemlerin sonuçları irdelendiğinde; ekonomik büyümenin en çok ücretli çalşsanlardaki cinsiyetler arası gelir eşitsizliği oranı üzerinde etkisinin olduğu görülmüştür. $\mathrm{Bu}$ sonuç ekonomik büyümenin en çok ücretli çalışanlardaki cinsiyetler arası gelir eşitsizliği oranını kadınların lehine olacak şekilde azalttığını göstermektedir. Lise ve dengi okul mezunu çalışanlardaki cinsiyetler arası gelir eşitsizliği oranı, ekonomik büyümenin etkilediği bir diğer değişkendir. Ücretli çalışanlarda olduğu gibi ekonomik büyüme, lise ve dengi okul mezunu çalş̧anlardaki cinsiyetler arası gelir eşitsizliği oranını kadınların lehine olacak şekilde azaltan bir faktördür.

Yevmiyeli, işveren, kendi hesabına çalışanlar ile okur-yazar olmayan, bir okul bitirmeyen, lise ve altı ve yükseköğretim mezunu çalışanlardaki cinsiyetler arası gelir eşitsizliği oranları üzerinde ise ekonomik büyüme oranının anlamlı bir etkisinin olmadı̆̆ tespit edilmiştir.

Ücretli, maaşlı çalışanların daha nitelikli çalışanlar olduğu, yevmiyeli çalışanların ise temizlik, tarımda ürün toplama gibi daha niteliksiz çalışanlar olduğu, işveren ve kendi hesabına çalışanların ise hem nitelikli hem de niteliksiz olabileceği göz önünde bulundurulduğunda ekonomik büyümenin nitelikli çalsşan olan ücretli, maaşlı kadın çalışanlara daha faydalı olduğu görülmektedir.

Eğitim durumuna göre cinsiyetler arası gelir eşitsizliği incelendiğinde en düşük oranların yükseköğretim mezunu çalışanlarda olduğu, yükseköğretim mezunu kadınların gelir eşitsizliğini en az yaşayan eğitim grubuna sahip kadınlar olduğu görülmektedir. Bu nedenle bu grupta anlamlı bir etki olmaması beklenen bir sonuçtur. Lise ve dengi mezunu çalışanlarda ekonomik büyümenin kadınlar lehine 
gelir eşitsizliğini azaltan bir faktör olarak ortaya çıkmasının nedeninin, bu guruptaki kadınların diğer alt gruptakilere nazaran daha nitelikli çalışanlar olmalarından kaynaklandığı düşünülmektedir. Lise ve altı, okul bitirmeyen, okur-yazar olmayanlar ise genelde niteliksiz çalışanlar olduğundan ve daha çok beden gücüne dayalı işlerde çalıştıklarından ekonomik büyümenin etkisinin olmaması normal karşılanmıştır.

Sonuçlar, ekonomik büyümenin en üst eğitim düzeyi tabakasındaki kadınların gelirlerinden ziyade orta düzeyde eğitimli ama nitelikli kadın çalışanların gelir eşitsizliğini azaltan bir faktör olduğu şeklinde yorumlanmıştır.

\section{Etik Beyan}

“Türkiye'de Toplumsal Cinsiyet Eşitsizllĭgi-Ekonomik Büyüme İlişkisi Üzerine Ekonometrik Analiz” başl1klı çalısmanın yazım sürecinde bilimsel, etik ve alıntı kurallarına uyulmuş; toplanan veriler üzerinde herhangi bir tahrifat yapılmamış ve bu çalışma herhangi başka bir akademik yayın ortamına değerlendirme için gönderilmemiştir. $\mathrm{Bu}$ araştırmada hazır veri seti kullanıldığı için etik kurul kararı zorunluluğu taşımamaktadır.

\section{Kaynakça}

Arora, R. U. (2012). Gender inequality, economic development, and globalization: A state level analysis of India. The Journal of Developing Areas, 147-164.

Aytekin, B. (2014). Toplumsal cinsiyet eșitsiz̨ligì kuram: türkiye'de kadn emeğinin etkinlik cö̌zümlemesi (Doktora Tezi). İnönü Üniversitesi Sosyal Bilimler Enstitüsü İktisat Ana Bilim Dalı, Malatya.

Baltacı, N., Karg1, B., Beken, G. H. ve Akyol, H. (2017). Ekonomik özgürlük, gelir eşitsizliği ve yolsuzluk ile büyüme arasındaki ilişkinin incelenmesi. Cataloging-In-Publication Data, 298-304.

Barro, R. J. (2000). Inequality and growth in a panel of countries. Journal of economic growth, 5(1), 5-32.

Boll, C., ve Lagemann, A. (2018). Gender pay gap in EU countries based on SES (2014). Luxembourg, Publication Office of the European Union.

Bruno, M., Ravallion, M. ve Squire, L. (1996). Policy Research Working Papers. World Bank.

Deininger, K. ve Squire, L. (1996). A new data set measuring income inequality. The World Bank Economic Review, 10(3), 565-591.

Dollar, D. ve Gatti, R. (1999). Gender inequality, income, and growth: are good times good for women? (Vol. 1). Washington DC. Development Research Group, The World Bank.

Duruoğlu, T. (2007). Emek piyasasında cinsiyetçi ücret ayrımı: Bursa Organize Sanayi bölgesinde bir araşıtırma. Iletisisim Kuram ve Araştrma Dergisi, 24, 61-76.

Forbes, K. J. (2000). A reassessment of the relationship between inequality and growth. American economic review, 90(4), 869-887.

Fortin, N., Lemieux, T. ve Firpo, S. (2010). Decomposition methods in economics. NBER Working Paper, 16045. doi: $10.3386 /$ w16045.

Gujarati, D. N. (1999). "Essentials of Econometrics" (2 ${ }^{\text {nd }}$ Edition). Irwin/McGraw-Hill, Boston (Aktaran: Kilıç, F. ve Torun M. (2018). Bireysel kredilerin enflasyon üzerindeki etkisi: Türkiye örneği. Yönetim ve Ekonomi Araștrmalar Dergisi, 16(1), 18-40.).

Gürler, Ö. K. ve Üçdoğruk, Ş. (2007). Türkiye’de cinsiyete göre gelir farklıllğının ayrıştırma yöntemiyle uygulanması. Journal of Yasar University, 2(6), 571-589.

Güriş, S., Akay, E. Ç. ve Güriş, B. (2017). Eviens ile temel ekonometri. İstanbul: Der Yayınları.

Illkkaracan, İ. ve Selim, R. (2003). The role of unemployment in wage determination: Further evidence on the wage curve from Turkey. Applied Economics, 35(14), 1589-1598.

Karasar, N. (2018). Arasstrmalarda rapor baz̨rlama. Ankara: Nobel Yayinevi,.

Kasnakoğlu, Z., ve Dayıŏlu, M. (1997). Kentsel Kesimde Kadın ve Erkeklerin İşgücüne Katıllımları ve Kazanç Farkllikları (Women's Labor Force Participation and Earnings Differentials between Genders in Turkey). METU Studies, 24(3), 329-361.

Karasar, N. (2018). Arasturmalarda Rapor Hazrrlama. Nobel Yayınevi, Ankara.

Kılıç, D. ve Öztürk, S. (2014). Türkiye'de Kadınların İşgücüne Katılımı Önündeki Engeller ve Çözüm Yolları: Bir Ampirik Uygulama. Amme İdaresi Dergisi, 47(1), 107- 130.

Klasen S. (1999). Does gender inequality reduce growth and development? Evidence from cross-country regressions. The World Bank, Washington D.C.

Koray, M. (2008). Sosyal politika (3. Baskı). Ankara: İmge Kitabevi.

Kuznets, S. (1955). Economic growth and income inequality. The American economic review, 45(1), 1-28.

Miller, C. ve Razavi, S. (1995). From WID to GAD: Conceptual shifts in the women and development discourse (No. 1). UNRISD Occasional Paper, 1-58.

Özkan, G. S. ve Özkan, B. (2010). Kadın çalışanlara yönelik ücret ayrımcılığı ve kadın ücretlerinin belirleyicilerine yönelik bir araştırma. Çalşsma ve Toplum, 1(24), 91-104. 
Partovi B., Safyar A. ve Amir G. (2011). The effect of gender inequality on economic growth, Economic modeling Quarterly, 3, 51-76.

Ravallion, M. (1997). Can high-inequality developing countries escape absolute poverty?. Economics letters, 56(1), 5157.

Seguino, S. (2000). Gender inequality and economic growth: A cross-country analysis. World Development, 28(7), 1211 1230.

Tansel, A. (2005). Public-private employment choice, wage differentials, and gender in Turkey. Economic development and cultural change, 53(2), 453-477.

Toksöz, G. (2011). Kalkınmada kadın emeği. İstanbul: Varlık Vayınları.

Topuz, S. G. ve Dağdemir, Ö. (2016). Ekonomik büyüme ve gelir eşitsizliği ilişkisi: Kuznets ters-u hipotezi'nin geçerliliğii. Eskişehir Osmangaz̧i Üniversitesi İktisadi ve İdari Bilimler Dergisi, 11(3), 115-130.

Turner, J. (1998). The Structure of Sociological Theory (Sixth Edition). Wadsworth Publishing Company.

Türkiye İstatistik Kurumu (Aralık, 2020). Erişim adresi https://www.tuik.gov.tr/.

\section{EXTENDED ABSTRACT}

Economic growth is a desired change as long as it provides greater prosperity to individuals, regions and nations. Economic growth has some benefits and drawbacks. The advantages of economic growth are the improvement of living standards, poverty reduction, improvement of working conditions and unemployment reduction. In addition, it is crucial for communities as economic growth increases income and consumption. In other words, people have a higher standard of living and consequently the aptness to produce and consume socially desirable goods and services are increased. Therefore, economic growth improves financial situation of people, which implies that higher incomes and higher growth rates will result in poverty reduction.

The disadvantage of economic growth is that there is an income gap between the rich and the poor, and the rich earn more compared to the poor.

The important factor in economic growth is the connection between production and distribution. Most researchers agree that the main purpose of economic growth is improving social welfare. However, the increase in per capita income does not indicate an improvement in social welfare, but only shows the potential for an increase in social welfare. Industrialization-development strategies and economic growth policies are only instrumental variables to increase social welfare.

The more the equal economic opportunities are given to people; the more opportunities arise to improve people's well-being. Economic growth contributes to poverty reduction, but poverty reduction depends on many factors, including levels of income distribution. While countries with economic growth tend to reduce poverty, the opposite is true for countries with lower growth. Consequently, improvements in living standards can only be achieved and sustained if the benefits of economic growth are widely shared in a society (people of all background, rich and poor, men and women, well educated and less educated, urban and rural).

In particular, gender equality and the distribution of well-being among men and women are a very important indicator for fair distribution. In many parts of the world, women have more equitable opportunities for better access to education, childcare, credit and employment that contribute to their human development. This tendency also contributes to the human development of other family members and to economic growth. Investing in women's talents and making them to use their choices is the most reliable way to contribute to the economic growth and overall development.

Many studies have been conducted on the relationship between gender inequality and economic growth. The issue of economic growth and social income inequality have always been a key question for researchers. Deininger and Squire (1996) created a new data set for a decade covering 88 countries on inequality. As a result of their analysis, they revealed that while income inequality increases in 45 countries, it decreases in 43 countries (Deininger and Squire. 1996, p.565-591).

Ravallion (1997) conducted specific empirical analyzes between economic growth and income inequality, based on the data obtained; he concluded that growth does not lead to an increase or decrease in inequality (Ravallion, 1997, p.54). Bruno, Ravallion, and Squire (1996) did not reveal a systematic relationship between growth and income inequality in their studies for India. It was identified that the reason for poverty reduction in India is due to the development in rural and urban sectors rather than the transition from rural to urban sectors (Bruno, Ravallion, M. and Squire, 1996, p.18). 
This study analyzed the effect on gender wage gap in Turkey's economic growth between 2005-2019. Quantitative research method was used within the scope of this research conducted by correlational survey model. This study applied correlational survey model, the current situation was accurately illustrated and it was attempted to determine it as it was.

Correlational survey model is based on examining the relationship between two or more variables (Karasar, 2018, p.53).This study aimed to reveal the effects on gender wage gap in Turkey's economic growth between 2005-2019. Answer to the question, "What impact has Turkey's economic growth had on gender wage gap, based on education and employment status in 2005-2019" has been identified within the scope of the research.

Logarithmic and difference operators have been done to stabilize the data. Data stationarity control was tested using the Augmented Dickey-Fuller test (ADF). This study applied LS-Least Squares (NLS and ARMA) methods to examine the effects of Economic Growth Independent Variable of gender wage gap on dependent variables such as employees, employers, self-employed, illiterate, people who dropped out school, people who completed junior high school, and those who completed high and equivalent school.

When the results of the equations created within the scope of the research were examined; economic growth was most likely to have an impact on the gender wage gap. This result shows that economic growth mostly decreases gender wage gap in favor of women. Another variable affected by economic growth is gender inequality among high and equivalent school graduates. Economic growth, as the increase in the number of employees, is a factor that narrows the gender pay gap in favor of women among high and equivalent school graduates.

The results of the study were interpreted as economic growth as a factor reducing the income inequality of middle-level educated but qualified female workers rather than the income of women in the top education level. 